\title{
TIME IRREVERSIBILITY AND COMPLEXITY OF HEART RATE VARIABILITY
}

\author{
Martynenko A., Raimondi G., Budreiko N.
}

Introduction. The heart rate variability is based on measuring (time) intervals between R-peaks (of RRintervals) of an electrocardiogram and plotting a rhythmogram on their basis with its subsequent analysis by various mathematical methods. Using nonlinear methods in HRV and ECG analysis has proven to be very advantageous. Time irreversibility is a fundamental parameter of a system, it defines justification and necessity of applying nonlinear methods for analysis of a system's dynamics.

Objective. We propose an algorithm for testing the probability of a time series' irreversibility, showing its effectiveness in the process of HRV analysis. In this article, complexity of HRV will be described by two parameters: entropy EnRE [18] and correlation dimension D2 [19]. Naturally, the chosen parameters EnRE and D2 in no way can be used for comprehensive description of complexity of HRV, but we will be able to tress the necessary sufficiency of such an approach.

Materials and methods. We used long-term HRV records by Massachusetts Institute of Technology Boston's Beth Israel Hospital (MIT-BIH) from [15], a free-access, on-line archive of physiological signals for Normal Sinus Rhythm (NSR) RR Interval, Congestive Heart Failure (CHF) RR Interval and Atrial Fibrillation (AF) Databases [16]. In [17], we have developed a special modification to the classic Mann-Whitney (MW) U-test in order to use the test for comparison of Time Series with an equal number of elements $N$ - Time Series MW $M$-test. Here the new statistical $\mathcal{M}$-test was proposed for finding the probability of time series' irreversibility.

Conclusion. In this article, we propose a statistical $\mathcal{M}$-test for assessment of probability of irreversibility of time series. It has been shown that the new statistical $\mathcal{M}$-test accurately identifies times series reversibility and irreversibility in known cases of synthetic data. For long-term HRV records of MIT-BIH database for NSR, CHF and AF groups, we have compared values of $z$-score, which statistically defines the limit of irreversibility of time series, and values of HRV complexity indicators: entropy EnRE [18] and correlation dimension D2 [19]. We have noted the following:

- HRV is time irreversible nonlinear dynamic process, with the exception of AF episodes;

- nonlinear indicators of HRV complexity - entropy EnRE and correlation dimension D2 - have been analyzed, and there is a conclusive difference between NSR and analyzed pathological states;

- analyzed time series have been presented in D2-z-EnRE phase space, and their reliable separability has been shown. It can be stated that the analyzed D2-z-EnRE phase space is sufficient for research of nonlinear HRV events in this case.

KEY WORDS: heart rate variability, time irreversibility, entropy, correlation dimension

\section{INFORMATION ABOUT AUTHORS}

Martynenko Alexander, D. Sc., Professor, Department of Hygiene and Social Medicine, V. N. Karazin Kharkiv National University, 6, Svobody sq., Kharkiv, Ukraine, 61022, e-mail: Alexander.v.martynenko@karazin.ua, ORCID ID: https://orcid.org/0000-0002-0609-2220

Gianfranco Raimondi, MD, PhD, Prof., Sapienza University of Rome (Italy), Piazzale Aldo Moro 5, 00185, Rome, Italy, e-mail: gianfrancoraimondi@uniroma1.it

Budreiko Nikita, Assistant, Department of hygiene and social medicine, V. N. Karazin Kharkiv National University School of Medicine, 6, Svobody sq., Kharkiv, Ukraine, 61022, e-mail: nbudreiko@ protonmail.com

\section{INTRODUCTION}

The heart rate variability $(\mathrm{HRV})$ is based on measuring (time) intervals between $\mathrm{R}$ peaks (of RR-intervals) of an electrocardiogram (ECG) and plotting a rhythmogram on their basis with its subsequent analysis by various mathematical methods that are classified as Time-Domain, Frequency-Domain and Nonlinear [1, 2]. Using nonlinear methods in HRV and ECG analysis has proven to be very advantageous, and they are reviewed in detail, for example, in $[3,4]$. Time irreversibility is a fundamental 
parameter of a system, it defines justification and necessity of applying nonlinear methods for analysis of a system's dynamics. At the same time, analysis of dynamics of a timereversible system can very well be limited to statistical or spectral methods. Analysis of an HRV time series' irreversibility has been a popular and oft-discussed topic in scientific literature for the last 20 years [4-9]. It has been noted in [7] that HRV 'nonlinear dynamics owing to time irreversibility at short time scales are significantly present during daytime in healthy subjects, more frequently present in the CHF population and less frequently during night-time in both groups, thus suggesting their link with a dominant sympathetic regulation and/or with a vagal withdrawal'. Assessments of time irreversibility have been conducted through a pair of irreversibility indexes [7]. In [10], based on calculation of Multiscale Time Asymmetry Index (MSTAI), it has been shown that MSTAI is highest for a time series from young subjects and decreases with aging or heart disease'. The lowest value of MSTAI has been recorded in patients with AF, when compared to NSR and CHF groups [10]. Lack of index assessments of time irreversibility is due to lack of possibility to draw a clear line between a reversible and an irreversible time series. In recent years, there has been a rise in popularity of those irreversibility assessment methods [11, 12] which allow to clearly identify and visualize the presence of a series' time irreversibility: horizontal visibility algorithm with KullbackLeibler divergence [11], Time Reversibility from Ordinal Patterns (TiROP) [12]. In [12], effectiveness of TiROP algorithm for analysis of electroencephalographic (EEG) signals has been demonstrated, and it has been shown 'that interictal EEG dynamics can be associate to a reversible linear process, whereas time irreversibility characterizes epileptic seizures'.

Classic definition of a time series' irreversibility refers to probabilistic nature of an observed event: 'a stationary process $\mathrm{X}(\mathrm{t})$ is said to be statistically time reversible if for every $\mathrm{N}$, the series $\left\{\mathrm{X}\left(\mathrm{t}_{1}\right), \cdot, \mathrm{X}\left(\mathrm{t}_{\mathrm{N}}\right)\right\}$ and $\left\{\mathrm{X}\left(\mathrm{t}_{\mathrm{N}}\right), \cdot, \mathrm{X}\left(\mathrm{t}_{1}\right)\right\}$ have the same joint probability distributions' [13]. That is why in this article we propose an algorithm for testing the probability of a time series' irreversibility, showing its effectiveness in the process of HRV analysis.

\section{MATERIALS AND METHODS}

We used long-term HRV records by Massachusetts Institute of Technology Boston's Beth Israel Hospital (MIT-BIH) from [15] (http://www.physionet.org), a freeaccess, on-line archive of physiological signals. Normal Sinus Rhythm (NSR) RR Interval Database includes beat annotation files for 54 long-term ECG recordings of subjects in normal sinus rhythm (30 men, aged 28.5 to 76 , and 24 women, aged 58 to 73). Congestive Heart Failure (CHF) RR Interval Database includes beat annotation files for 29 long-term ECG recordings of subjects aged 34 to 79 , with congestive heart failure (NYHA classes I, II, and III). Subjects include 8 men and 2 women; gender of the remaining 21 subjects is not known. The original electrocardiography (ECG) signals for both NSR and CHF RR interval databases were digitized at $128 \mathrm{~Hz}$, and the beat annotations were obtained by automated analysis with manual review and correction. The MIT-BIH Atrial Fibrillation (AF) Database [16] includes 25 long-term ECG recordings of human subjects with atrial fibrillation (mostly paroxysmal). The individual recordings are each 10 hours in duration, and contain two ECG signals each sampled at 250 samples per second with 12bit resolution over a range of \pm 10 millivolts. The original analog recordings were made at Boston's Beth Israel Hospital (now the Beth Israel Deaconess Medical Center) using ambulatory ECG recorders with a typical recording bandwidth of approximately $0.1 \mathrm{~Hz}$ to $40 \mathrm{~Hz}$.

In [17], we have proposed a special modification to the classic Mann-Whitney (MW) U-test in order to use the test for comparison of Time Series with an equal number of elements $N$ - Time Series MW $M$ test with a formula for $M$ :

$$
\begin{gathered}
M=U-a b s\left(D_{1}-D_{2}\right) \\
D_{1}^{2}=\sum_{i=0}^{N}\left(r_{1}^{i}-R_{1}^{i}\right)^{2}
\end{gathered}
$$




$$
D_{2}^{2}=\sum_{i=0}^{N}\left(r_{2}^{i}-R_{2}^{i}\right)^{2}
$$

In this case, $r_{1}, r_{2}$ are ranks of the elements in original time series, $R_{1}, R_{2}$ are ranks of time series in a general series after merging. In the proposed modification, we have taken into account the changed positions of elements of a time series before and after merging of data into a single sequence by calculating their total distances $D_{1}, D_{2}$. The critical values of Time Series MW $M$-test are the same for MW U-test $(\mathrm{N}<20)$; for sample sizes larger than 20, we can use the normal as follows:

$$
Z=\begin{gathered}
M-E(M) \\
\sigma
\end{gathered}
$$

where

$$
E(M)=\frac{1}{7} N^{2} ; \sigma^{2}=N^{2} \frac{(2 N+1)}{1 \%} .
$$

The critical value is the normal tabled $Z$ for $\alpha / 2$ for a two-tailed test, e.g. $Z=1.96$ for significance level of $\mathrm{p}<0.05$.

In case we want to test one and the same time series (observed and reversed in time), for finding the probability of its time irreversibility the $M$ formula proposed above should be altered in the aspect of distance calculation $D_{1}, D_{2}$ :

$$
\begin{aligned}
& \mathcal{D}_{1}-\sum_{i \in\left[r_{1}^{i}>R_{1}^{i}\right]} \sqrt{1+\left(r_{1}^{i}-R_{1}^{i}\right)^{2}}+ \\
& +\sum_{i \in\left[r_{1}^{i}>R_{1 r \varepsilon v}^{i}\right]} \sqrt{1+\left(r_{1}^{i}-R_{1 \text { rev }}^{i}\right)^{2}} \\
& \mathcal{D}_{2}=\sum_{i \in\left[r_{2}^{i}=R_{2}^{i}\right]} \sqrt{1+\left(r_{2}^{i}-R_{2}^{i}\right)^{2}}+ \\
& +\sum_{i \in\left[r_{2}^{i}>R_{2 r \varepsilon v}^{i}\right]} \sqrt{1+\left(r_{2}^{i}-R_{2 \text { rev }}^{i}\right)^{2}}
\end{aligned}
$$

and final formula for testing time irreversibility:

$$
\begin{gathered}
\mathcal{M}=U-a b s\left(\mathcal{D}_{1}-\mathcal{D}_{2}\right), \\
Z=\frac{\mathcal{M}-E(\mathcal{M})}{\sigma},
\end{gathered}
$$

where $r_{1}$ are ranks of the elements in original time series, $r_{2}$ are ranks of the elements in reversed time series, $R_{1}, R_{2}$ are ranks of time series in a general series after merging, $R_{1 \text { rev }}, R_{2 \text { rev }}$ are ranks of time series in a reversed general series after merging.

In this article, complexity of HRV will be described by two parameters: entropy EnRE [18] and correlation dimension D2 [19]. There are a lot of definitions for complexity, but 'one of the most consensual is that complexity is a property of every system that quantifies the amount of structured information' [20]. Naturally, the chosen parameters EnRE and D2 in no way can be used for comprehensive description of complexity of HRV, but we will be able to tress the necessary sufficiency of such an approach.

\section{RESULTS AND DISCUSSION}

First of all, let us test the proposed algorithm's possibilities for finding the time irreversibility of known time series. Reversible processes include realization of stationary Gaussian linear process; irreversible time series is including nonGaussian stochastic processes and dissipative chaos [11]. Presented in Table 1 are two time reversible processes, - Linear Gaussian Process (LGP), a linear auto-regressive model of second order driven by a white noise AR(2); irreversible classic chaotic systems Lorenz, Duffing, Rossler, Hennon and dissipative chaos system - Logistic map. Additionally, a combination of chaotic systems Lorenz and LGP has been analyzed to study the impact of noise on the algorithm's accuracy when calculating time irreversibility. In all cases, there has been a show of high selective ability of the proposed $M$ test for finding time irreversibility of known time series, even in the presence of noise. Verdict on time irreversibility of a time series has been given for significance level of $\mathrm{p}<0.05$, with a critical number of $z=1.96$. 
Irreversibility test for known synthetic time series

Table 1

\begin{tabular}{|c|c|}
\hline Model & $Z$ score (reversibility $\mathrm{z}<1.96, \mathrm{p}<0.05$ ) \\
\hline \multicolumn{2}{|c|}{ Reversible $(z<1.96)$} \\
\hline LGP (Gaussian noise with distribution $\mathrm{M}=0 ; \sigma=1$ ) & $0.93 \pm 0.74$ \\
\hline $\operatorname{AR}(2)\left(x_{t+2}=0.7 x_{t+1}+0.2 x_{t}+\varepsilon_{t}, \varepsilon_{t}-\right.$ white noise $)$ & $1.18 \pm 0.76$ \\
\hline \multicolumn{2}{|c|}{ Irreversible $(z>1.96)$} \\
\hline Lorenz & $3.28 \pm 2.46$ \\
\hline Lorenz + LGP & $2.92 \pm 2.16$ \\
\hline Logistic & $5.88 \pm 4.36$ \\
\hline Duffing & $6.49 \pm 3.30$ \\
\hline Rossler & $6.30 \pm 3.56$ \\
\hline Hennon & $2.19 \pm 1.16$ \\
\hline
\end{tabular}

We shall note that, from the point of view of the proposed $M-$ test for finding time irreversibility, there are two mechanisms for altering the $z$ score:

1. Presence of time asymmetry of a series. Chaotic attractors have asymmetrical time structures, and the $\mathcal{M}$ test identifies those. In an LGP series, values are distributed randomly without forming any significant asymmetrical structures. That is why reversion of such a series does not cause time asymmetry, and such a series is statistically reversible. A series symmetrical in time is completely reversible with $z \approx 0$.

2. Recurrent values. A chaotic attractor or an LGP series does not have strictly recurring values, and that is why, with sufficient accuracy of a series' presentation, this factor does not impact their $z$ value. In an HRV series, presence of recurring values is a common event. Moreover, increasing number of recurring RR values leads to a decrease in Total Power (TP) and is identified as a state of metronomization of heart rate, which is in and of itself confirmed as a strong, independent predictor of future health problems and as a correlate of all-cause mortality $[21,22]$. In Table 2 , it is shown that the percentage of recurrent RR values can increase from Recurrence $=4.79 \pm 2.33 \%$ in NSR group, to Recurrence $=11.3 \pm 8.16 \%$ in CHF group and to $30-40 \%$ of recurrent RR values in AF group. That is why there has to be a special mechanism in the test's $\mathcal{M}-$ algorithm, for taking into account the impact of recurrent $R R$ values.

Table 2

Time irreversibility and complexity of HRV for different groups of patients

\begin{tabular}{|c|c|c|c|c|c|c|}
\hline & & $z$ & $\begin{array}{c}\text { Recurrence, } \\
\%\end{array}$ & $\mathbf{T P}, \mathrm{ms}^{2}$ & D2 & $E n R E$ \\
\hline Normal Sinı & Rhythm & $3.19 \pm 1.78^{*}$ & $4.79 \pm 2.33^{*}$ & $1734 \pm 1508^{*}$ & $2.10 \pm 0.28^{*}$ & $1.72 \pm 0.47^{*}$ \\
\hline Congestive & art Failure & $5.07 \pm 2.41^{*}$ & $11.3 \pm 8.16^{*}$ & $758 \pm 1061^{*}$ & $1.93 \pm 0.22^{*}$ & $0.65 \pm 0.76^{*}$ \\
\hline Atrial & before $\mathrm{AF}$ & $3.32 \pm 0.73^{* * *}$ & $28.1 \pm 9.72^{*}$ & $493 \pm 206^{* * *}$ & $1.95 \pm 0.93^{* *}$ & $0.98 \pm 0.15^{* *}$ \\
\hline Fibrillation & $\mathrm{AF}$ & $1.55 \pm 0.47^{*}$ & $8.25 \pm 0.45^{*}$ & $4372 \pm 1128^{*}$ & $8.44 \pm 0.82^{*}$ & $1.23 \pm 0.05^{*}$ \\
\hline (AF) & after $\mathrm{AF}$ & $3.58 \pm 0.81^{* * *}$ & $38.0 \pm 12.3^{*}$ & $707 \pm 184^{* *}$ & $1.88 \pm 0.83^{* * *}$ & $0.91 \pm 0.19^{* *}$ \\
\hline
\end{tabular}

*-difference significant on the $p<0.05 ;{ }^{* *}$ - difference significant from AF on the $p<0.05$ 
Let us analyze the results shown in Table 2 , in greater detail:

Normal Sinus Rhythm (NSR)

An HRV time series is irreversible in time on average $\mathrm{z}=3.19 \pm 1.78$ ( $\mathrm{p}<0.05$ when compared to $z=1.96$ ). Recurrence is the lowest of analyzed groups, having the value of $4.79 \pm 2.33 \%$. Correlation rate of Recurrence and TP is average, statistically significant and equals -0.69. Correlation dimension D2 and entropy EnRE is differing from groups $\mathrm{CHF}$ and $\mathrm{AF}$ (before, during and after AF episodes) with significance level $\mathrm{p}<$ 0.05 .

\section{Congestive Heart Failure (CHF)}

An HRV time series is irreversible in time with $\mathrm{z}=5.07 \pm 2.41$, which is statistically conclusively higher than in NSR group. This result is consistent with [7], noted in which is a higher degree of nonlinear dynamics and time irreversibility (during daytime and nighttime) in the CHF population when compared to healthy subjects. We shall note that $\quad$ Recurrence $=11.3 \pm 8.16 \%$ also increases more than twofold when compared to NSR group. Correlation rate of Recurrence and TP is average, statistically significant and equals -0.62 . Correlation dimension D2 is conclusively lower than in NSR group and does not differ from $\mathrm{AF}$ group before and after Atrial Fibrillation episodes. Value of entropy EnRE is the lowest of all analyzed groups and conclusively differs from them at the level of $\mathrm{p}<0.05$.

\section{Atrial Fibrillation (AF)}

Before and After AF episodes

An HRV time series before AF episodes is irreversible in time with $\mathrm{z}=3.32 \pm 0.73$, after $\mathrm{AF}$ episodes with $\mathrm{z}=3.58 \pm 0.81$, which statistically conclusively does not differ from NSR group. Recurrence values are the highest of all analyzed groups and equal $28.1 \pm 9.72 \%$ before $\mathrm{AF}$ episodes and
$38.0 \pm 12.3$ after AF episodes. Entropy EnRE, correlation dimension D2 and TP are conclusively lower than during AF episodes (see Fig. 1 and Fig. 2).

\section{During AF episodes}

During AF episodes, an HRV time series is reversible in time $\mathrm{z}=1.55 \pm 0.47$, and this value is conclusively lower than before and after AF episodes. This is consistent with the calculations in [10], where, through multiscale time asymmetry index (MSTAI), it is shown that the lowest MSTAI value is recorded in patients with $\mathrm{AF}$, when compared to NSR and CHF groups. However, unlike our study, in [10] there is no conclusion to the effect that during AF episodes an HRV time series becomes reversible in time. Recurrence $=8.25 \pm 0.45 \%$ lowers signifycantly, but it still exceeds values in the NSR about twofold. Entropy EnRE, correlation dimension D2 and TP grow significantly during AF episodes (see Fig. 1 and Fig. 2).

The MIT-BIH Atrial Fibrillation (AF) Database with 10-hours records was divided for $\mathrm{N}=500$ subsets and researched for Correlation Dimension D2 evolution before AF episodes and during AF. Figure 1. shows typical pattern of correlation dimension D2 evolution before atrial fibrillation episode: each epoch on the Fig. 1 consists of short RRs records $(\mathrm{N}=500)$; epoch with \# ' 0 ' is the beginning of AF episode according to MIT-BIH reference rhythm annotations. Correlation dimension D2 does not have significant difference from mean record value under Normal rhythm intervals except 5-6 epochs before AF episodes. The D2 significantly drop for about 30 minutes (or 5 6 epoch by $\mathrm{N}=500 \mathrm{RRs}$ ) before AF: D2 drop shown from epoch \# ' -5 ' on the Figure 1. During AF the D2 growth 4-5 times over the mean value. 


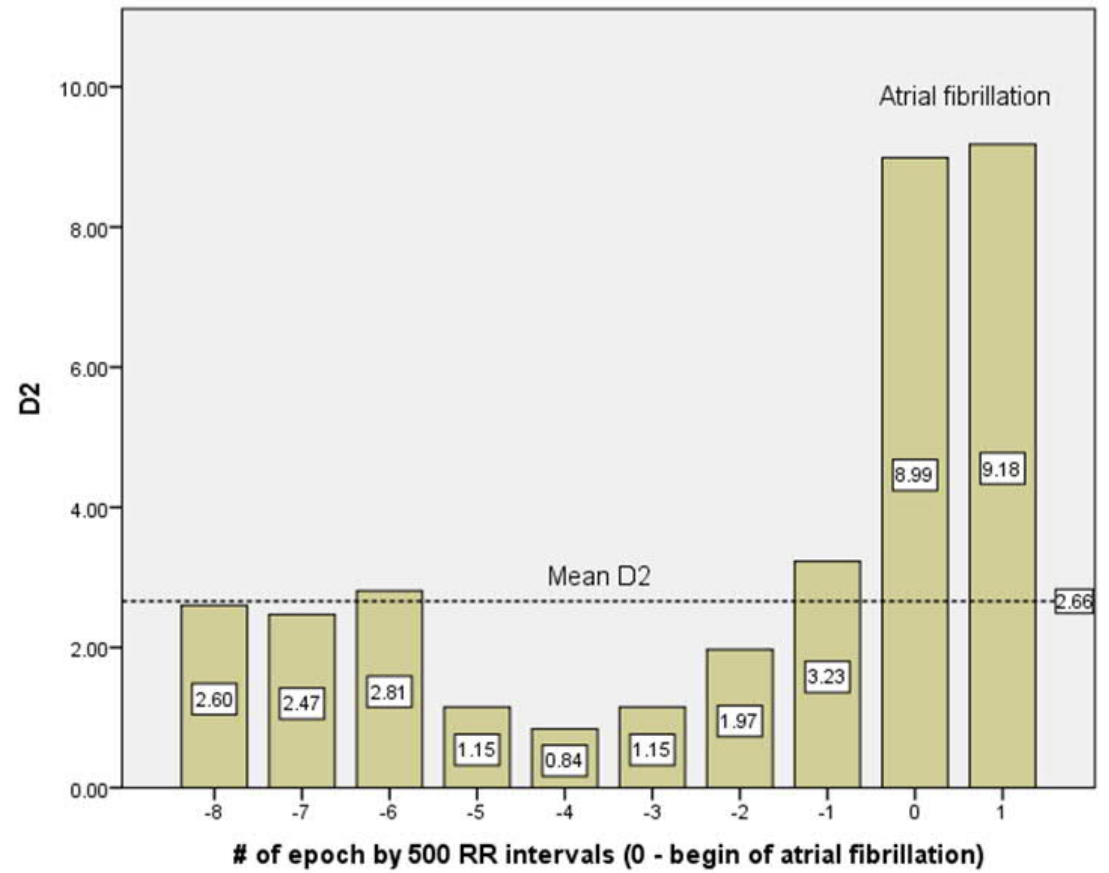

Fig. 1. Typical pattern of Correlation Dimension D2 before atrial fibrillation episode (MIT-BIH AF Database [16]).

Figure 2. shows typical pattern of entropy EnRE evolution before atrial fibrillation episode: each epoch on the Figure 2. consists of short RRs records $(\mathrm{N}=500)$; epoch with \# ' 0 ' is the beginning of AF episode according to MIT-BIH reference rhythm annotations.
EnRE growth significantly over mean level for the 10-15 minutes before AF episodes.

Finally on the Fig.3 we put together synthetic time series and HRV of different patient's groups in D2-z-EnRE phase space. It is obvious that the presented set of variables is sufficient for clear separation of each state.

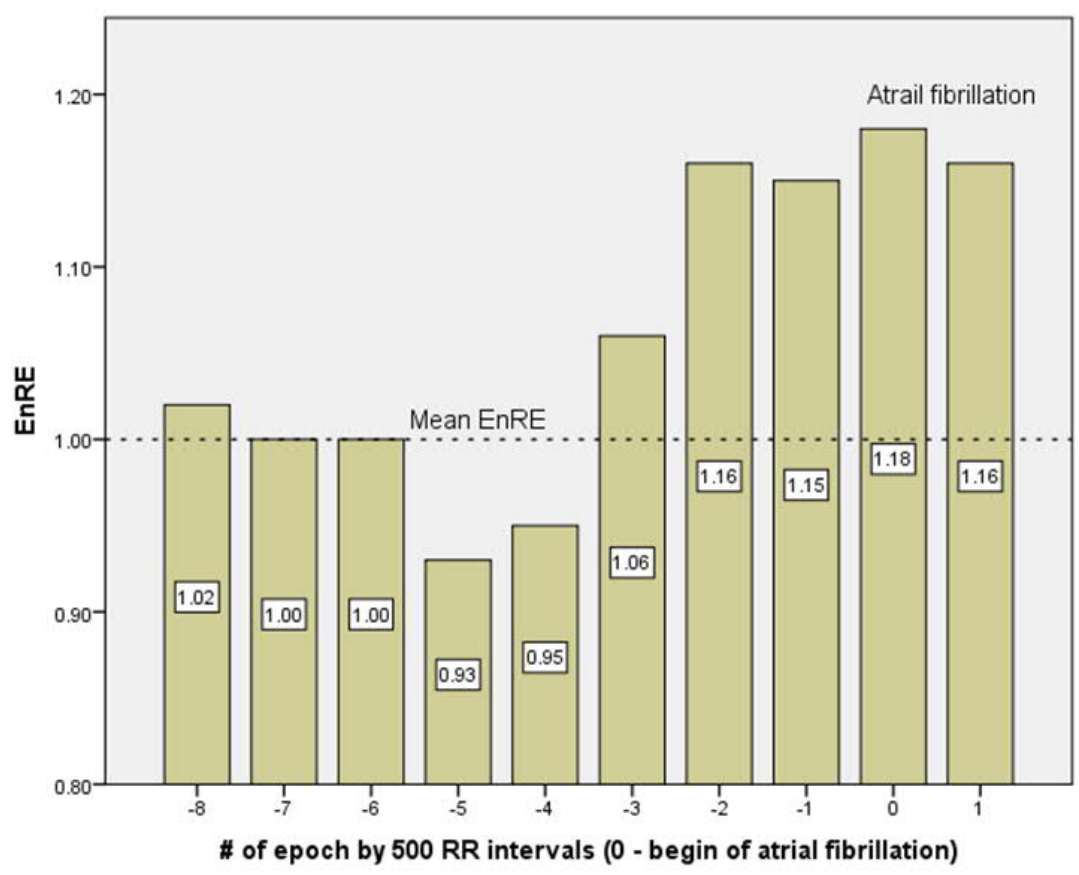

Fig. 2. Typical pattern of Entropy EnRE before atrial fibrillation episode (MIT-BIH AF Database [16]). 


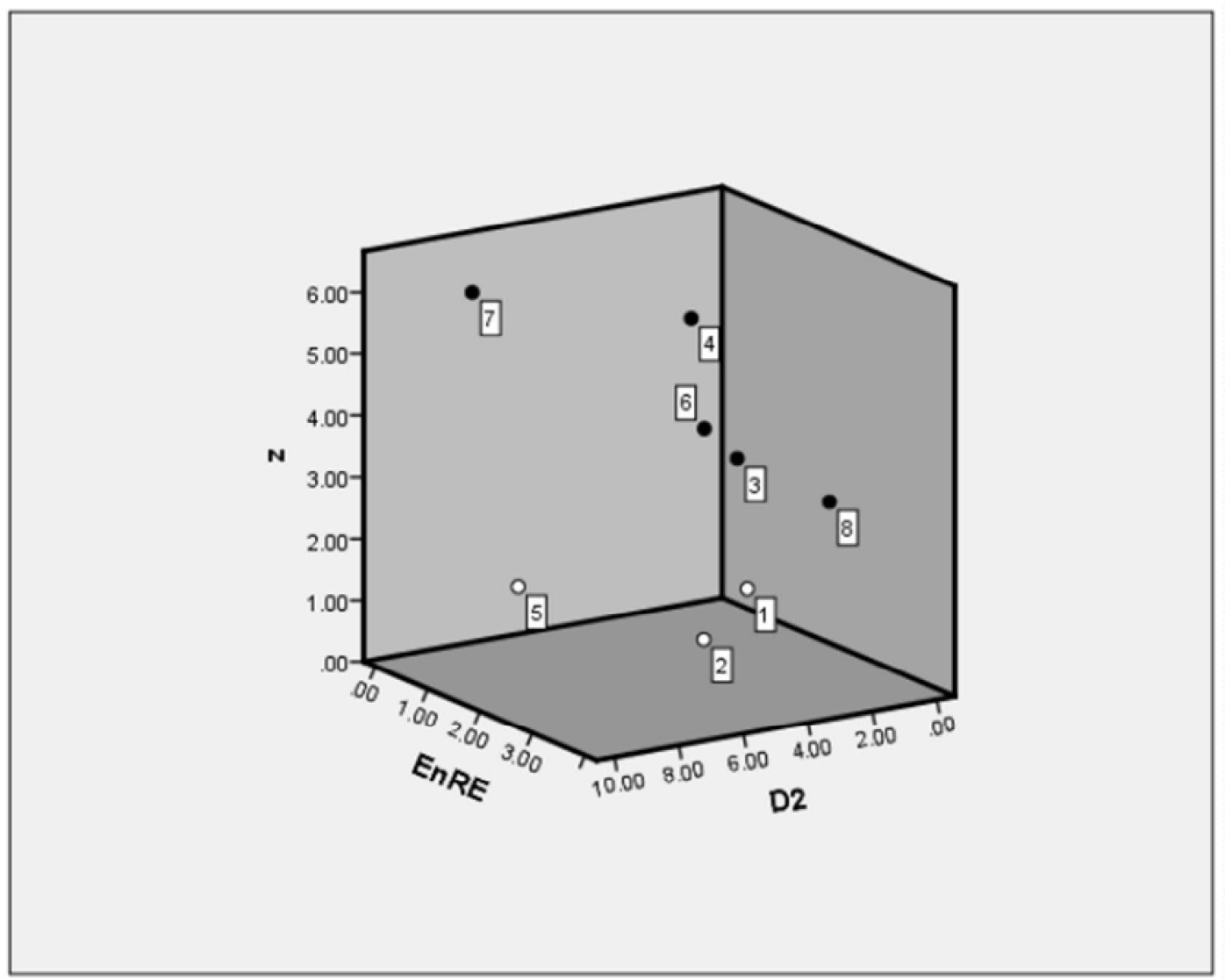

Fig, 3. Synthetic time series and HRV of different patient's groups in D2-z-EnRE phase space: $1^{*}$. Gaussian noise with distribution $(\mathrm{M}=0 ; \sigma=1) ; 2^{*}$. Harmonic signal $(\mathrm{a}+\mathrm{bsin}(\pi \mathrm{c}))$; 3. NSR; 4. CHF; $5^{*}$. AF episodes; 6. before and after AF; 7. Logistic attractor; 8. Lorenz attractor

* 1,2 and 5 are time reversible.

\section{CONCLUSIONS}

In this article, we propose a statistical test for assessment of probability of irreversibility of time series. The test is based on a special modification to the classic Mann-Whitney (MW) U-test, proposed by the authors in [17] in order to use the test for comparison of Time Series with an equal number of elements $N$ - Time Series MW $M$-test. It has been shown that the new statistical $M-$ test accurately identifies times series irreversibility in known cases of synthetic data, including: Linear Gaussian Process (LGP), a linear auto-regressive model of second order driven by a white noise $\operatorname{AR}(2)$; irreversible classic chaotic systems Lorenz, Duffing, Rossler, Hennon and dissipative chaos system - Logistic map (Tab.1). Also demonstrated is the test's robustness towards Gaussian noise, which is usually problematic in other approaches to finding time irreversibility.

For long-term HRV records of MIT-BIH database for Normal Sinus Rhythm (NSR), Congestive Heart Failure (CHF) and Atrial Fibrillation (AF), we have compared values of $z$-score, which statistically defines the limit of irreversibility of time series, and values of HRV complexity indicators: entropy EnRE [18] and correlation dimension D2 [19]. We have analyzed the behavior of said nonlinear HRV parameters in each specific case and noted the following:

- heart rate variability is time irreversible nonlinear dynamic process, with the exception of AF episodes;

- nonlinear indicators of HRV complexity entropy EnRE and correlation dimension D2 - have been analyzed, and there is a conclusive difference between Normal Sinus Rhythm and analyzed pathological states; 
- we have noted inverse correlation between TP and Recurrence (of RR) on the level of 62-69\%;

- we have demonstrated the peculiarities in behavior of entropy EnRE and correlation dimension D2 with relation to emergence of AF episodes;

- analyzed time series, including synthetic time series and implementation of HRV in NSR, CHF and AF groups, have been presented in D2-z-EnRE phase space, and their reliable separability has been shown (Fig. 3);

- taking the aforementioned into account, it can be stated that the analyzed D2-z-EnRE phase space is sufficient for research of nonlinear HRV events in this case.

\section{REFERENCES}

1. Task force of the European society of cardiology and the North American society of pacing and electrophysiology. Heart rate variability - standards of measurement, physiological interpretation, and clinical use. Circulation. 1996;93(5):1043-1065.

2. Yabluchansky N, Martynenko A. Heart Rate Variability for clinical practice. 2010. Kharkiv, Univer. Press, 131 p. [in Russ.] depositary: http://dspace.univer.kharkov.ua/handle/ 123456789/1462

3. Nayak SK at all. A Review on the Nonlinear Dynamical System Analysis of Electrocardiogram Signal. J Healthc Eng. 2018:6920420. https://doi.org/10.1155/2018/6920420

4. De Godoy MF. Nonlinear Analysis of Heart Rate Variability: A Comprehensive Review. Journal of Cardiology and Therapy, 2016;3(3):528-533.

5. Braun C, Kowallik P, Freking A, Hadeler D, Kniffki K.-D. \& Meesmann M. Demonstration of nonlinear components in heart rate variability of healthy persons. Am. J. Physiol. 1998;275:H1577-H1584.

6. Porta A, Guzzetti S, Montano N, Gnecchi-Ruscone T, Furlan R, Malliani A. Time Reversibility in ShortTerm Heart Period Variability. Computers in Cardiology. 2006;33:77-80.

7. Porta A. at all. Assessment of cardiovascular regulation through irreversibility analysis of heart period variability: a 24 hours Holter study in healthy and chronic heart failure populations. Phil. Trans. R. Soc. A. 2009;367:1359-1375. https://doi.org/10.1098/rsta.2008.0265

8. Anne Humeau-Heurtier, Guillaume Mahé, François Chapeau-Blondeau, David Rousseau, Pierre Abraham (2012). Study of time reversibility/irreversibility of cardiovascular data: theoretical results and application to laser Doppler flowmetry and heart rate variability signals. Phys Med Biol. 2012;Jul7;57(13):4335-51. https://doi.org/10.1088/0031-9155/57/13/4335

9. WenpoYao, WenliYao, JunWang. Equal heartbeat intervals and their effects on the nonlinearity of permutation-based time irreversibility in heart rate. Physics Letters A. 2019;383(15):1764-1771.

10. Madalena Costa, Ary L. Goldberger, C.-K. Peng. Broken. Asymmetry of the Human Heartbeat: Loss of Time Irreversibility in Aging and Disease. Phys. Rev. Lett. 1995;95:198102. https://doi.org/10.1103/PhysRevLett.95.198102

11. Lucas Lacasa, Angel Nunez, Edgar Rold’an, Juan M.R. Parrondo, Bartolo Luque. Time series irreversibility: a visibility graph approach. Physics of Condensed Matter. 2012: 14. https://doi.org/10.1140/epjb/e2012-20809-8

12. Mart' 1 nez JH, Herrera-Diestra JL and Chavez M. Detection of time reversibility in time series by ordinal patterns analysis. Chaos. 2018;28:123111. https://doi.org/10.1063/1.5055855

13. Weiss G. Time-reversibility of linear stochastic processes. J. Appl. Prob. 1975;12:831-836.

14. Goldberger AL. at all. Physiobank, physiotoolkit, and physionet: Components of a new research resource for complex physiologic signals. Circulation. 2000;101:215-220.

15. Moody GB, Mark RG. A new method for detecting atrial fibrillation using R-R intervals. Computers in Cardiology. 1983;10:227-230.

16. Martynenko A, Raimondi G, Sotnikova-Meleshkina Zh, Danylenko H, Budreiko N. Statistical Analysis of Medical Time Sseries. Journal of V. N. Karazin` KhNU Series «Medicine». 2020; 40: 5-12. https://doi.org/10.26565/2313-6693-2020-40-01

17. Martynenko A. Robust correlation dimension estimator for heart rate variability. Klin.inform.telemed. 2020;15(16):62-69.

18. Martynenko A, Raimondi G, Budreiko N. Robust entropy estimator for heart rate variability. Klin.inform.telemed. 2019;14(15): 67-73. https://doi.org/ 10.31071/kit2019.15.06

19. Teresa Henriques, Maria Ribeiro, Andreia Teixeira, Luísa Castro, Luís Antunes and Cristina Costa-Santos. Nonlinear Methods Most Applied to Heart-Rate Time Series. A Review. Entropy. 2020;22:309. https://doi.org/10.3390/e22030309 
20. Fredric Shaffer, Rollin McCraty, Christopher L. Zerr. A healthy heart is not a metronome: An integrative review of the heart's anatomy and heart rate variability. Frontiers in Psychology. 2014;5(1040):1-19. https://doi.org/10.3389/fpsyg.2014.01040

21. Francesco Sessa, Valenzano Anna, Giovanni Messina, Giuseppe Cibelli, Vincenzo Monda, Gabriella Marsala, Maria Ruberto, Antonio Biondi, Orazio Cascio, Giuseppe Bertozzi, Daniela Pisanelli, Francesca Maglietta, Antonietta Messina, Maria P. Mollica and Monica Salerno. Heart rate variability as predictive factor for sudden cardiac death. Aging (Albany NY). 2018;Feb,10(2):166-177. https://doi.org/10.18632/aging.101386 


\section{НЕЗВОРОТНІСТЬ І СКЛАДНІСТЬ ВАРІАБЕЛЬНОСТІ СЕРЦЕВОГО РИТМУ}

Мартиненко О., Раймонді Д., Будрейко М.

Вступ. Варіабельність серцевого ритму базується на вимірюванні (часу) інтервалів між R-піками (RR-інтервалів) електрокардіограми з поданням їх у вигляді ритмограми і подальшого аналізу різними математичними методами. Ефективність нелінійних методів аналізу ВСР і ЕКГ була показана численними дослідженнями. Необхідність застосування нелінійних методів аналізу динаміки системи обгрунтовується наявністю часової незворотності, як фундаментального властивості системи.

Мета. У статті запропоновано статистичний тест для оцінки ймовірності незворотності часового ряду і показана його ефективність при аналізі ВСР. Складність ВСР описана двома параметрами: ентропією $E n R E$ [18] і кореляційної розмірністю D2 [19]. Безумовно, вибрані величини, - EnRE i D2 ніяк не можуть претендувати на повноту опису комплексності ВСР, однак виявити необхідну достатність такого підходу ми зможемо.

Матеріали та методи. Аналіз коротких записів BCP (N = 500 RR) виконувався на підставі 24годинних записів ВСР з бази даних МIT-BIH [15] для пацієнтів з нормальним синусовим ритмом (NSR), серцевою недостатністю (CHF) і фібриляції передсердь (AF) [16]. В роботі [17] нами була запропонована спеціальна модифікація класичного статистичного U-тесту Манна-Вітней (MW) для порівняння часових рядів з однаковим числом елементів $\mathrm{N}-M$-тест для часових рядів. У цій статті був запропонований новий статистичний $\mathcal{M}$-тест для оцінки ймовірності незворотності часового ряду.

Результати і висновки. Новий статистичний $\mathcal{M}$-тест для оцінки ймовірності незворотності часового ряду був розроблений і протестований на сукупності відомих прикладів оборотних i необоротних часових рядів. Для коротких записів ВСР, обраних з 24-годинних записів бази даних ВСР MIT-BIH для NSR, CHF i AF груп, був виконаний їх аналіз на незворотність (z-score) і показників комплексності ВCP: ентропії EnRE [18] і кореляційної розмірності D2 [19]. Було відзначено наступне:

- $\mathrm{BCP}$ - це незворотний в часі нелінійний динамічний процес, за винятком епізодів фібриляції передсердь;

- проаналізовані нелінійні показники комплексності BCP - ентропія EnRE і кореляційний розмірність D2 і було показано їх достовірну відміну для нормального синусового ритму від розглянутих патологічних станів;

- в тривимірному фазовому просторі D2-z-EnRE були представлені розглянуті часові ряди $\mathrm{i}$ продемонстровано, що вони цілком сепарабельні. Таким чином, фазовий простір D2-z-EnRE $\epsilon$ достатнім для дослідження нелінійних явищ ВСР в даному випадку.

КЛЮЧОВІ СЛОВА: варіабельність серцевого ритму, незворотність, ентропія, кореляційний розмірність

\section{ИНФОРМАЦІЯ ПРО АВТОРІВ}

Мартиненко Олександр, д.фіз-мат.н., професор кафедри гігієни та соціальної медицини Харківського національного університету імені В. Н. Каразіна, пл. Свободи, 6, Харків, Україна, 61022, e-mail: Alexander.v.martynenko@karazin.ua, ORCID ID: https://orcid.org/0000-0002-0609-2220

Ж. Раймонди, д.мед.н., проф., Римський університет Ла Сапієнца (Італія), Piazzale Aldo Moro 5, 00185, Рим, Італія, e-mail: gianfrancoraimondi@uniroma1.it

Будрейко Микита, асистент кафедри гігієни та соціальної медицини Харківського національного університету імені В. Н. Каразіна, майдан Свободи, 6, Харків, Україна, 61022, e-mail: nbudreiko@ protonmail.com

\section{НЕОБРАТИМОСТЬ И СЛОЖНОСТЬ ВАРИАБЕЛЬНОСТИ СЕРДЕЧНОГО РИТМА}

Мартыненко А., Раймонди Д., Будрейко Н.

Введение. Вариабельность сердечного ритма базируется на измерении (времени) интервалов между R-пиками (RR-интервалов) электрокардиограммы с представлением их в виде ритмограммы и последующего анализа различными математическими методами. Эффективность нелинейных методов анализа ВСР и ЭКГ была показана многочисленными исследованиями. Необходимость применения нелинейных методов анализа динамики системы обосновывается наличием временной необратимости, как фундаментального свойства системы.

Цель. В статье предложен статистический тест для оценки вероятности необратимости временного ряда и показана его эффективность при анализе ВСР. Сложность ВСР описана двумя параметрами: энтропией $E n R E$ [18] и корреляционной размерностью D2 [19]. Безусловно, выбранные величины, - 
$E n R E$ и D2 никак не могут претендовать на полноту описания комплексности ВСР, однако оценить необходимую достаточность такого подхода мы сможем.

Материалы и методы. Анализ коротких записей $\mathrm{BCP}(\mathrm{N}=500 \mathrm{RR})$ выполнялся на основании 24часовых записей ВСР из базы данных МIT-BIH [15] для пациентов с нормальным синусовым ритмом (NSR), сердечной недостаточностью (CHF) и фибрилляцией предсердей (AF) [16]. В работе [17] нами была предложена специальная модификация классического статистического U-теста Манна-Витней (MW) для сравнения временных рядов с одинаковым числом элементов $N-M$-тест для временных рядов. В настоящей статье был предложен новый статистический $\mathcal{M}$-тест для оценки вероятности необратимости временного ряда.

Результаты и выводы. Новый статистический $\mathcal{M}$-тест для оценки вероятности необратимости временного ряда был разработан и протестирован на совокупности известных примеров обратимых и необратимых временных рядов. Для коротких записей ВСР, выбранных из 24-часовых записей базы данных BCP MIT-B для NSR, CHF и AF групп, был выполнен их анализ на необратимость (z-score) и показателей комплексности ВCP: энтропии EnRE [18] и корреляционной размерности D2 [19]. Было отмечено следующее:

- ВСР - это необратимый во времени нелинейный динамический процесс, за исключением эпизодов фибрилляции предсердий;

- проанализированы нелинейные показатели комплексности $\mathrm{BCP}$ - энтропия EnRE и корреляционная размерность D2 и было показано их достоверное отличие для нормального синусового ритма от рассмотренных патологических состояний;

- в трехмерном фазовом пространстве D2-z-EnRE были представлены рассмотренные временные ряды и продемонстрировано, что они вполне сепарабельны. Таким образом, фазовое пространство $\mathrm{D} 2-z-E n R E$ является достаточным для исследования нелинейных явлений ВСР в данном случае.

КЛЮЧЕВЫЕ СЛОВА: вариабельность сердечного ритма, необратимость, энтропия, корреляционная размерность

\section{ИНФОРМАЦИЯ ОБ АВТОРАХ}

Мартыненко Александр, д.физ-мат.н., профессор кафедры гигиены и социальной медицины Харьковского национального университета имени В.Н. Каразина, пл. Свободи, 6, Харьков, Украина, 61022, e-mail: Alexander.v.martynenko@karazin.ua, ORCID ID: https://orcid.org/0000-0002-0609-2220

Ж. Раймонди, д.мед.н., проф., Университет Рима «Сапиенза», Рим, Италия, Piazzale Aldo Moro 5, 00185, Рим, Италия, e-mail: gianfrancoraimondi@uniroma1.it

Будрейко Никита, асистент кафедры гигиены и социальной медицины Харьковского национального университета имени В. Н. Каразина, пл. Свободи, 6, Харьков, Украина, 61022, e-mail: nbudreiko@ protonmail.com

Отримано: 18.12 .2020 p. Прийнято до друку: 09.02.2021 p. 